Volume 4 Nomor 1, Februari 2019, halaman 49-62

\title{
PENGARUH KECERDASAN EMOSIONAL DAN RASA PERCAYA DIRI TERHADAP PENGUASAAN KONSEP MATEMATIKA
}

\section{THE EFFECT OF EMOTIONAL INTELLIGENCE AND SELF- CONFIDENCE ON MASTERY OF MATHEMATICAL CONCEPTS}

\author{
Muh. Aripin Nurmantoro \\ STKIP Al-Amin Indramayu, Jl. PU Kemped Desa Wirakanan - Kandanghaur, \\ aripin.nurmantoro@gmail.com
}

\begin{abstract}
ABSTRAK
Penelitian ini dilakukan dengan tujuan untuk mengetahui pengaruh langsung antara kecerdasan emosional terhadap rasa percaya diri dan pengaruh langsung antara kecerdasan emosional dan rasa percaya diri terhadap penguasaan konsep matematika. Penelitian ini dilakukan dengan metode survey, dengan jumlah sampel 75 (tujuh puluh lima) orang yang diambil menggunakan teknik Multi Stage Sampling. Instrumen yang digunakan adalah angket dan hasil tes matematika siswa. Data diolah dengan bantuan Microsoft Excel dan SPSS 20, dan dianalisis dengan menggunakan metode analisis jalur. Berdasarkan hasil analisis data diketahui bahwa (1) terdapat pengaruh langsung kecerdasan emosional terhadap penguasaan konsep matematika; (2) terdapat pengaruh langsung rasa percaya diri siswa terhadap penguasaan konsep matematika; dan (3) terdapat pengaruh langsung kecerdasan emosional terhadap rasa percaya diri.
\end{abstract}

Kata Kunci: Kecerdasan Emosional, Rasa Percaya Diri, Penguasaan Konsep Matematika

\section{ABSTRACT}

The purpose of this study are to find out the direct effect between emotional intelligence on selfconfidence and the direct influence between emotional intelligence and self-confidence on mastering mathematical concepts. This research was conducted by survey method, with a total sample of 75 (seventy five) people taken using Multi Stage Sampling techniques. The instruments used were questionnaires and students' mathematics test results. Data is processed with the help of Microsoft Excel and SPSS 20, and analyzed using the path analysis method. Based on the results of data analysis it is known that (1) there is a direct influence of emotional intelligence on mastering mathematical concepts; (2) there is a direct influence of students' confidence in mastering mathematical concepts; and (3) there is a direct influence of emotional intelligence on selfconfidence.

Keywords: Emotional Intelligence, Confidence, Mastery of Mathematical Concepts

How to Cite: Nurmantoro, M. A. (2019). Pengaruh Kecerdasan Emosional dan Rasa Percaya Diri Terhadap Penguasaan Konsep Matematika. Mathline: Jurnal Matematika dan Pendidikan Matematika, Vol.4, No.1, 49-62. 


\section{PENDAHULUAN}

Pendidikan merupakan usaha atau aktivitas yang disengaja dan memiliki tujuan yang didalamnya terlibat berbagai faktor yang saling berkaitan antara satu dengan lainnya sehingga membentuk suatu sistem yang saling mempengaruhi (Yahya, 2009). Pendidikan pada hakikatnya merupakan usaha manusia untuk memanusiakan manusia itu sendiri, dalam artian untuk membudayakan manusia. Disamping itu, tujuan pelaksanaan pembelajaran pada dasarnya adalah untuk memperoleh hasil belajar berupa penguasaan konsep belajar berupa kemampuan menangkap pengertian-pengertian seperti mampu mengungkapkan suatu materi yang disajikan ke dalam bentuk yang lebih dipahami serta mampu memberikan interpretasi dan mampu mengaplikasikannya. Sugiyono (2011) berpendapat bahwa matematika merupakan alat efisien dan diperlukan oleh semua ilmu pengetahuan. Dalam hal ini penguasaan konsep matematika merupakan tingkat kemampuan yang mengharapkan siswa memahami arti, situasi dan fakta yang diketahui serta dapat menjelaskan dengan menggunakan kata-kata sendiri sesuai dengan pengetahuan yang dimilikinya tanpa mengubah arti maupun maknanya.

Belakangan ini masyarakat mulai menyadari bahwa keberhasilan siswa bukan hanya dipengaruhi oleh kecerdasan intelektual saja, tetapi juga dipengaruhi oleh kecerdasan emosional. Hal tersebut dipertegas dengan pendapat Uno (2010) yang menyatakan bahwa yang diperlukan untuk sukses dimulai dengan keterampilan intelektual, tetapi orang juga memerlukan kecakapan emosi untuk memanfaatkan potensi bakat mereka secara penuh. Siswa yang mengikuti pelajaran dalam keadaan emosional tidak stabil dimungkinkan karena adanya persoalan yang dihadapi sehingga tidak akan menunjukkan sikap penerimaan pelajaran dengan baik. Persoalan-persoalan yang dihadapi siswa tersebut dapat terjadi kapan saja sehingga persoalan tersebut bisa dibawa dari rumah atau terjadi ketika berselisih paham dengan teman-temannya. Safaria \& Saputra (2012) berpendapat bahwa setiap individu pasti akan menghadapi sebuah permasalahan, orang yang tidak memiliki kecerdasan emosi cenderung bersikap negatif dalam menghadapi permasalahan. Disisi lain, terdapat faktor lain yang juga menentukan hasil belajar matematika siswa diantaranya adalah rasa percaya diri. Rasa Percaya diri merupakan salah satu aspek kepribadian yang sangat penting dalam kehidupan manusia, hal itu memiliki korelasi karena orang yang percaya diri memiliki pengharapan yang realistis, bahkan ketika harapan mereka tidak terwujud, mereka tetap berpikiran positif dan dapat menerimanya. 
Matematika di SMP yang tersusun berdasarkan materi-materi yang satu dengan lainnya saling berhubungan, artinya penguasaan terhadap materi yang satu akan mempengaruhi penguasaan terhadap materi selanjutnya. Mengingat banyaknya cakupan yang perlu dibahas dalam mata pelajaran matematika, maka untuk mendapatkan hasil terbaik setiap siswa harus belajar dengan teratur dan sistematik. Russeffendi (2006) menyatakan bahwa "topik-topik dalam matematika itu tersusun secara hierarkis mulai dari yang mendasar atau mudah sampai kepada yang paling sukar". Dalam penelitain ini, secara umum bertujuan untuk mengetahui pengaruh langsung: (1) kecerdasan emosional terhadap penguasaan konsep matematika; (2) rasa percaya diri siswa terhadap penguasaan konsep matematika; dan (3) kecerdasan emosional terhadap rasa percaya diri siswa.

Kecerdasan emosional pertama kali diperkenalkan pada tahun 1990 oleh psikolog Peter Salovely dari Harvard University dan John Mayer dari University of New Hampshire untuk menerangkan kualitas-kualitas emosional yang tampaknya penting bagi keberhasilan. Kualitas-kualitas ini antara lain: empati, mengungkapkan dan memahami perasaan, mengendalikan amarah, kemandirian, kemampuan menyesuaikan diri, disukai, kemampuan memecahkan masalah antarpribadi, ketekunan, kesetiakawanan, keramahan, dan sikap hormat (Shapiro, 2001). Sajiman (2013) berpendapat bahwa kecerdasan merupakan suatu kemampuan tertinggi dari jiwa makhluk hidup yang hanya dimiliki oleh manusia. Kecerdasan ini diperoleh sejak lahir, dan sejak itulah potensi kecerdasan ini mulai berfungsi mempengaruhi tempo dan kualitas perkembangan individu, dan manakala sudah berkembang, maka fungsinya akan semakin berarti lagi bagi manusia yaitu akan mempengaruhi kualitas penyesuaian dirinya dengan lingkungannya. Firmansyah (2010) menyatakan bahwa emosi adalah suatu perasaan (afek) yang mendorong individu untuk merespon atau bertingkah laku terhadap stimulus, baik yang berasal dari dalam maupun dari luar dirinya. Kecerdasan emosi menuntut kita untuk belajar mengakui dan menghargai perasaan pada diri kita dan orang lain dan menanggapinya dengan tepat, menerapkan dengan efektif informasi dari energi emosi emosi dalam kehidupan dan pekerjaan seharihari. Menurut Lawrence (Abdullah, 2015). Berdasarkan beberapa pendapat tersebut, disimpulkan bahwa kecerdasan emosi merupakan kemampuan di bidang emosi yaitu kemampuan menghadapi frustasi, kemampuan mengendalikan emosi, optimisme, dan kemampuan menjalin hubungan dengan orang lain atau empati. Disamping itu juga kecerdasan emosional dapat memberikan motivasi siswa dalam upaya meningkatkan minat belajar dan dapat pula memudahkan seseorang dalam berinteraksi dengan orang lain dan lingkungannya. 
Menurut Hakim (Rohayati, 2011) menyatakan bahwa percaya diri setiap orang merupakan salah satu kekuatan jiwa yang sangat menentukan berhasil tidaknya orang tersebut dalam mencapai berbagai tujuan hidupnya. Sedangkan menurut Saputra yang dikutip Muhamad (2016) dinyatakan bahwa percaya diri adalah salah satu kunci kesuksesan siswa dalam belajar, karena tanpa adanya rasa percaya diri siswa tidak akan sukses dalam berinteraksi dengan temannya. Rasa percaya diri merupakan hal yang sangat essensial dalam semua aspek kehidupan, orang yang kekurangan rasa percaya diri sulit untu sukses. Hal ini dimungkinkan karena dalam dirinya tumbuh tidak percaya akan usaha yang dilakukan akan memberikan hasil yang memuaskan (Pohan, 2005). Menurut Alo Liliweri (Abdullah, 2015) menyatakan bahwa rasa percaya diri merupakan kemampuan melihat diri sendiri dengan segala kekurangan dan kelebihannya. Selain itu, Sumardiono (2006) menyatakan bahwa rasa percaya diri dalam diri siswa dapat mendorong tumbuhnya minat belajar. Berdasarkan deskripsi tersebut dapat disimpulkan bahwa rasa percaya diri merupakan suatu kepercayaan terhadap diri sendiri yang dimiliki setiap individu dalam memandang dirinya secara utuh untuk bertingkah laku sesuai dengan yang diharapkan sebagai suatu perasaan.

Konsep dapat diartikan sebagai serangkaian perangsang dengan sifat-sifat yang sama, konsep yang sederhana dapat didefinisikan sebagai pola unsur bersama di antara anggota kumpulan atau rangkaian (Sudjana, 2010). Pemahaman konsep matematika adalah kemampuan bersikap, berpikir dan bertindak yang ditunjukkan oleh siswa dalam memahami definisi, pengertian, ciri khusus, hakikat dan inti/isi dari matematika dan kemampuan dalam memilih prosedur secara efisien dan tepat (Gusniwati, 2015). Menurut Nasution (2005) siswa yang menguasai konsep dapat mengidentifikasi dan mengerjakan soal baru yang lebih bervariasi. Selain itu, apabila anak memahami suatu konsep maka ia akan dapat menggeneralisasikan suatu objek dalam berbagai situasi lain yang tidak digunakan dalam situasi belajar. Pengertian pemahaman yang dikemukakan oleh para ahli seperti yang dikemukakan oleh Winkel \& Mukhtar (Sudaryono, 2012) mengemukakan bahwa pemahaman yaitu kemampuan seseorang untuk mengerti atau memahami sesuatu setelah sesuatu itu diketahui atau diingat; mencakup kemampuan untuk menangkap makna dari arti dari bahan yang dipelajari, yang dinyatakan dengan menguraikan isi pokok dari suatu bacaan, atau mengubah data yang disajikan dalam bentuk tertentu ke bentuk yang lain. Berdasarkan pendapat tersebut dapat disimpulkan bahwa penguasaan konsep sebagai kemampuan siswa dalam memahami makna secara ilmiah baik teori maupun penerapannya dalam kehidupan sehari-hari. 
Tujuan penelitian ini diantaranya untuk mengetahui pengaruh langsung antara kecerdasan emosional terhadap rasa percaya diri dan pengaruh langsung antara kecerdasan emosional dan rasa percaya diri terhadap penguasaan konsep matematika.

\section{METODE PENELITIAN}

Penelitian survei mengilustrasikan prinsip-prinsip penelitian korelasional dan melengkapinya dengan cara yang tepat dan efektif untuk mendeskripsikan pemikiran, pendapat, dan perasaan orang (Emzir, 2014). Penelitian dilaksanakan di 3 (tiga) Sekolah Menengah Pertama (SMP), dan pelaksanaan penelitian dilaksanakan pada semester genap tahun pelajaran 2017/2018. Sedangkan metode yang digunakan dalam penelitian ini adalah metode survey korelasional. Populasi dalam penelitian ini adalah seluruh siswa kelas VII SMP Negeri di Kabupaten Indramayu Provinsi Jawa Barat. Sampel dalam penelitian ini diambil dari populasi terjangkau dengan teknik Multistage Sampling, sampel yang digunakan sebanyak 75 siswa dengan rincian sebagai berikut.

Tabel 1. Penetapan Jumlah Sampel

\begin{tabular}{clc}
\hline No. & Nama Sekolah & Jumlah Sampel \\
\hline 1 & SMP Negeri 4 Gabuswetan & 25 Orang \\
2 & SMP Negeri 2 Patrol & 25 Orang \\
3 & MTs Negeri 13 Indramayu & 25 Orang \\
& J U M L A H & 75 Orang \\
\hline
\end{tabular}

Pengumpulan data dalam penelitian ini dinyatakan dalam tabel berikut.

Tabel 2. Metode Pengumpulan Data

\begin{tabular}{ll}
\hline Variabel Penelitian & Teknik Pengumpulan Data \\
\hline Kecerdasan emosional & Angket \\
Rasa percaya diri & Angket \\
Pengusaan konsep matematika & Hasil tes materi bangun datar \\
\hline
\end{tabular}

Mengingat masalah dalam matematika sangat komplek, sehingga untuk memudahkan dalam mengakomodir permasalahan yang muncul maka disusun kisi-kisi instrumen penguasaan konsep matematika sebagai berikut.

Tabel 3. Kisi-kisi Instrumen Penguasaan Konsep Matematika

\begin{tabular}{cl}
\hline No. & \multicolumn{1}{c}{ Kompetensi Dasar } \\
\hline 1 & Mengidentifikasi sifat-sifat berdasarkan sisi dan sudut bangun datar \\
2 & Mengidentifikasi sifat-sifat bangun datar \\
3 & Menghitung keliling dan luas bangun datar
\end{tabular}


54 Pengaruh Kecerdasan Emosional dan Rasa Percaya Diri Terhadap Penguasaan Konsep Matematika

\begin{tabular}{cc}
\hline No. & Kompetensi Dasar \\
\hline 4 & Melukis segitiga, garis tinggi, garis bagi, garis berat dan garis sumbu \\
\hline
\end{tabular}

\section{HASIL DAN PEMBAHASAN}

Hasil perhitungan dan pengujian yang dilakukan dengan bantuan komputer melalui program aplikasi SPSS 20, serta analisis dan intepretasinya sebagai berikut.

Tabel 4. Deskripsi Data Penelitian

\begin{tabular}{llrrr} 
& \multicolumn{2}{c}{ Statistics } & & \\
\hline & $\begin{array}{c}\text { Kecerdasan } \\
\text { Emosional }\end{array}$ & $\begin{array}{c}\text { Rasa } \\
\text { Percaya } \\
\text { Diri }\end{array}$ & $\begin{array}{c}\text { Penguasaa } \\
\text { n Konsep }\end{array}$ \\
\hline $\mathrm{N}$ & Valid & 75 & 75 & 75 \\
& Missin & 0 & 0 & 0 \\
Mean & $\mathrm{g}$ & 77.53 & 75.52 & 81.79 \\
Std. Deviation & 4.894 & 6.473 & 4.757 \\
Variance & 23.955 & 41.902 & 22.630 \\
Minimum & 65 & 60 & 65 \\
Maximum & 92 & 95 & 93 \\
\hline
\end{tabular}

1. Uji Persyaratan Analisis Data

a. Uji Normalitas

Untuk menentukan kriteria normalitas, maka ditentukan sebagai berikut.

Jika nilai Asymp. Sig.(2-tailed) > 0,05; maka data berdistribusi normal.

Jika nilai Asymp. Sig.(2-tailed) <0,05; maka data tidak berdistribusi normal.

Tabel 5. Hasil Perhitungan Uji Normalitas

One-Sample Kolmogorov-Smirnov Test

\begin{tabular}{|c|c|c|c|c|}
\hline & & $\begin{array}{c}\text { Kecerdasan } \\
\text { Emosional }\end{array}$ & $\begin{array}{c}\text { Rasa } \\
\text { Percaya } \\
\text { Diri }\end{array}$ & $\begin{array}{c}\text { Penguasaan } \\
\text { Konsep }\end{array}$ \\
\hline \multirow[t]{2}{*}{$\mathrm{N}$} & & 75 & 75 & 75 \\
\hline & Mean & 77.53 & 75.52 & 81.79 \\
\hline Normal Parameters ${ }^{\mathrm{a}, \mathrm{b}}$ & $\begin{array}{l}\text { Std. } \\
\text { Deviation }\end{array}$ & 4.894 & 6.473 & 4.757 \\
\hline \multirow{3}{*}{$\begin{array}{l}\text { Most Extreme } \\
\text { Differences }\end{array}$} & Absolute & .134 & .151 & .126 \\
\hline & Positive & .134 & .151 & .126 \\
\hline & Negative & -.089 & -.077 & -.097 \\
\hline \multicolumn{2}{|c|}{ Kolmogorov-Smirnov Z } & 1.159 & 1.309 & 1.095 \\
\hline \multicolumn{2}{|l|}{ Asymp. Sig. (2-tailed) } & .136 & .065 & .182 \\
\hline
\end{tabular}

a. Test distribution is Normal.

b. Calculated from data.

Berdasarkan hasil perhitungan diatas maka disimpulkan bahwa semua data berdistribusi normal. 
b. Uji Linearitas

Hasil perhitungan pengujian linieritas garis regresi hubungan antara variabel kecerdasan emosional dengan variabel penguasaan konsep sebagai berikut.

Tabel 6. Hasil Pengujian Linieritas

Kecerdasan Emosional Terhadap Penguasaan Konsep

ANOVA Table

\begin{tabular}{|c|c|c|c|c|c|c|c|}
\hline & & & $\begin{array}{c}\text { Sum of } \\
\text { Squares }\end{array}$ & Df & $\begin{array}{l}\text { Mean } \\
\text { Square }\end{array}$ & $\mathbf{F}$ & Sig. \\
\hline Penguas & Between & (Combined) & 732.426 & 18 & 40.690 & 2.419 & .006 \\
\hline & Groups & Linearity & 531.366 & 1 & 531.366 & 31.583 & .000 \\
\hline $\begin{array}{l}\text { Konsep } \\
*\end{array}$ & & $\begin{array}{l}\text { Deviation from } \\
\text { Linearity }\end{array}$ & 201.060 & 17 & 11.827 & .703 & .786 \\
\hline Kecerda & Within G & oups & 942.160 & 56 & 16.824 & & \\
\hline $\begin{array}{l}\text { san } \\
\text { Emosio } \\
\text { nal }\end{array}$ & Total & & $\begin{array}{r}1674.58 \\
7\end{array}$ & 74 & & & \\
\hline
\end{tabular}

Pada tabel di atas terlihat bahwa nilai pada kolom Sig. baris deviation from Linierity $=0,786$ untuk semua sampel lebih besar dari 0,05, sehingga dengan kata lain bahwa garis regresi hubungan antara varibel kecerdasan emosional dan variabel penguasaan konsep dapat dikategorikan linier. Sedangkan hasil perhitungan pengujian linieritas garis regresi hubungan antara variabel rasa percaya diri dengan variabel penguasaan konsep sebagai berikut.

Tabel 7. Hasil Pengujian Linieritas

Rasa Percaya Diri Terhadap Penguasaan Konsep

ANOVA Table

\begin{tabular}{|c|c|c|c|c|c|c|c|}
\hline & & & $\begin{array}{l}\text { Sum of } \\
\text { Squares }\end{array}$ & Df & $\begin{array}{c}\text { Mean } \\
\text { Square }\end{array}$ & $\mathbf{F}$ & Sig. \\
\hline \multirow{5}{*}{$\begin{array}{l}\text { Penguasa } \\
\text { an } \\
\text { Konsep * } \\
\text { Rasa } \\
\text { Percaya } \\
\text { Diri }\end{array}$} & Between & (Combined) & 841.506 & 19 & 44.290 & 2.924 & .001 \\
\hline & Groups & Linearity & 490.556 & 1 & 490.556 & 32.387 & .000 \\
\hline & & $\begin{array}{l}\text { Deviation from } \\
\text { Linearity }\end{array}$ & 350.950 & 18 & 19.497 & 1.287 & .232 \\
\hline & \multicolumn{2}{|c|}{ Within Groups } & 833.081 & 55 & 15.147 & & \\
\hline & \multicolumn{2}{|l|}{ Total } & $\begin{array}{r}1674.58 \\
7\end{array}$ & 74 & & & \\
\hline
\end{tabular}

Pada tabel di atas terlihat bahwa nilai pada kolom Sig. baris Deviation from Linierity $=0,232$ untuk semua sampel lebih besar dari 0,05, sehingga dengan kata lain bahwa garis regresi hubungan antara varibel rasa percaya diri dan variabel penguasaan konsep dapat dikategorikan linier. Sedangkan hasil perhitungan pengujian linieritas garis regresi hubungan antara variabel kecerdasan emosional dengan variabel rasa percaya diri sebagai berikut. 
Tabel 8. Hasil Pengujian Linieritas

Kecerdasan Emosional Terhadap Rasa Percaya Diri

ANOVA Table

\begin{tabular}{|c|c|c|c|c|c|c|}
\hline & & $\begin{array}{c}\text { Sum of } \\
\text { Squares }\end{array}$ & Df & $\begin{array}{c}\text { Mean } \\
\text { Square }\end{array}$ & $\mathbf{F}$ & Sig. \\
\hline Rasa & Between (Combined) & 1350.764 & 18 & 75.042 & 2.401 & .007 \\
\hline Percaya & Groups Linearity & 1168.464 & 1 & 1168.464 & 37.392 & .000 \\
\hline Diri * & Deviation & & & & & \\
\hline $\begin{array}{l}\text { Kecerda } \\
\text { san }\end{array}$ & $\begin{array}{l}\text { from } \\
\text { Linearity }\end{array}$ & 182.300 & 17 & 10.724 & .343 & .991 \\
\hline Emosion & Within Groups & 1749.956 & 56 & 31.249 & & \\
\hline al & Total & 3100.720 & 74 & & & \\
\hline
\end{tabular}

Pada tabel di atas terlihat bahwa nilai pada kolom Sig. baris Deviation from Linierity $=0,991$ untuk semua sampel lebih besar dari 0,05, dengan kata lain bahwa garis regresi hubungan antara varibel kecerdasan emosional dan variabel rasa percaya diri dapat dikategorikan linier.

\section{c. Uji Multikolinearitas}

Variabel bebas yang terdiri dari variabel kecerdasan emosional dan rasa percaya diri pada analisis regresi disyaratkan tidak ada kolinearitas/multikolinearitas.

Tabel 9. Hasil Perhitungan Uji Multikolinearitas

Coefficients $^{\text {a }}$

\begin{tabular}{llrr}
\hline \multirow{2}{*}{ Model } & \multicolumn{2}{c}{ Collinearity Statistics } \\
& Tolerance & \multicolumn{1}{c}{ VIF } \\
\hline \multirow{2}{*}{$1 \quad$ Kecerdasan Emosional } & .623 & 1.605 \\
& Rasa Percaya Diri & .623 & 1.605 \\
\hline
\end{tabular}

a. Dependent Variable: Penguasaan Konsep Matematika

Abdullah (2014) menyatakan bahwa, kolinearitas tidak ada jika nilai Variance Inflactor Factor (VIF) lebih besar dari 10. Sehingga data tersebut dapat dinyatakan bahwa tidak ada kolinearitas/multikolinearitas pada regresi ganda ini.

2. Pengujian Hipotesis Penelitian

Penghitungan analisis korelasi ini menggunakan SPSS 20 sebagai alat bantu dengan hasil sebagai berikut.

Tabel 10. Hasil Perhitungan Korelasi

Correlations

\begin{tabular}{llrrr}
\hline & & $\begin{array}{c}\text { Penguasaan } \\
\text { Konsep }\end{array}$ & $\begin{array}{c}\text { Kecerdasan } \\
\text { Emosional }\end{array}$ & $\begin{array}{c}\text { Rasa } \\
\text { Percaya } \\
\text { Diri }\end{array}$ \\
\hline \multirow{3}{*}{ Pearson } & Penguasaan Konsep & 1.000 & .563 & .541 \\
Correlation & Kecerdasan & .563 & 1.000 & .614 \\
& Emosional & .541 & .614 & 1.000 \\
\hline
\end{tabular}


Correlations

\begin{tabular}{llrrr}
\hline & & $\begin{array}{c}\text { Penguasaan } \\
\text { Konsep }\end{array}$ & $\begin{array}{c}\text { Kecerdasan } \\
\text { Emosional }\end{array}$ & $\begin{array}{c}\text { Rasa } \\
\text { Percaya } \\
\text { Diri }\end{array}$ \\
\hline \multirow{3}{*}{ Sig. (1-tailed) $)$} & Kenguasaan Konsep &. & .000 & .000 \\
& Emosional & .000 &. & .000 \\
& Rasa Percaya Diri & .000 & .000 &. \\
$\mathrm{~N}$ & Penguasaan Konsep & 75 & 75 & 75 \\
& Kecerdasan & 75 & 75 & 75 \\
& Emosional & 75 & 75 & 75 \\
\hline
\end{tabular}

a. Menentukan Koefisien Jalur Berdasarkan Koefisien Korelasi

Untuk menentukan koefisien jalur berdasarkan koefisien korelasi digunakan program SPSS 20 sebagai alat bantu dengan hasil sebagai berikut.

Tabel 11. Koefisien Jalur $P_{31}$ dan $P_{32}$

Coefficients $^{\mathrm{a}}$

\begin{tabular}{|c|c|c|c|c|c|c|}
\hline \multirow{2}{*}{\multicolumn{2}{|c|}{ Model }} & \multicolumn{2}{|c|}{$\begin{array}{l}\text { Unstandardized } \\
\text { Coefficients }\end{array}$} & \multirow{2}{*}{$\begin{array}{c}\text { Standardized } \\
\text { Coefficients } \\
\text { Beta } \\
\end{array}$} & \multirow{2}{*}{$\mathbf{t}$} & \multirow{2}{*}{ Sig. } \\
\hline & & B & $\begin{array}{l}\text { Std. } \\
\text { Error }\end{array}$ & & & \\
\hline \multirow{3}{*}{1} & (Constant) & 36.440 & 7.098 & & 5.134 & .000 \\
\hline & $\begin{array}{l}\text { Kecerdasan } \\
\text { Emosional }\end{array}$ & .360 & .114 & .371 & 3.151 & .002 \\
\hline & $\begin{array}{l}\text { Rasa Percaya } \\
\text { Diri }\end{array}$ & .230 & .086 & .314 & 2.665 & .009 \\
\hline
\end{tabular}

a. Dependent Variable: Penguasaan Konsep

Tabel 12. Koefisien Jalur $P_{21}$

Coefficients $^{\mathrm{a}}$

\begin{tabular}{|c|c|c|c|c|c|c|}
\hline \multirow[t]{2}{*}{ Model } & & \multicolumn{2}{|c|}{$\begin{array}{l}\text { Unstandardized } \\
\text { Coefficients }\end{array}$} & \multirow{2}{*}{$\begin{array}{c}\text { Standardized } \\
\text { Coefficients } \\
\text { Beta }\end{array}$} & \multirow[t]{2}{*}{$\mathbf{t}$} & \multirow[t]{2}{*}{ Sig. } \\
\hline & & B & Std. Error & & & \\
\hline \multirow{2}{*}{1} & (Constant) & $\begin{array}{r}12.57 \\
2\end{array}$ & 9.493 & & 1.324 & .190 \\
\hline & $\begin{array}{l}\text { Kecerdasan } \\
\text { Emosional }\end{array}$ & .812 & .122 & .614 & 6.644 & .000 \\
\hline
\end{tabular}

a. Dependent Variable: Rasa Percaya Diri

b. Pengujian Hipotesis Koefisien Jalur

1) Pengujian Hipotesis Kesatu

$\mathrm{H}_{0}$ : tidak terdapat pengaruh langsung kecerdasan emosional terhadap penguasaan konsep matematika. 
$\mathrm{H}_{1}$ : terdapat pengaruh langsung kecerdasan emosional terhadap penguasaan konsep matematika.

Berdasarkan analisis jalur diketahui bahwa koefisien jalur variabel kecerdasan emosional terhadap penguasaan konsep matematika $P_{31}=0,371$. Untuk $\alpha=0,05$ pada uji dua pihak diperoleh nilai $\mathrm{t}_{\text {tabel }}=1,980$. Karena nilai $\mathrm{t}_{\text {hitung }} 3,151>\mathrm{t}_{\text {tabel }}$ 1,980 maka dapat disimpulkan bahwa terdapat pengaruh langsung Kecerdasan Emosional terhadap penguasaan konsep matematika.

2) Pengujian Hipotesis Kedua

$\mathrm{H}_{0}$ : terdapat pengaruh langsung rasa percaya diri terhadap penguasaan konsep matematika.

$\mathrm{H}_{1}$ : tidak terdapat pengaruh langsung rasa percaya diri terhadap penguasaan konsep matematika.

Berdasarkan analisis jalur diketahui bahwa koefisien jalur variabel Rasa percaya diri siswa terhadap penguasaan konsep matematika $P_{32}=0,314$. Untuk $\alpha=0,05$ pada uji dua pihak diperoleh nilai $\mathrm{t}_{\text {tabel }}=1,980$, karena nilai $\mathrm{t}_{\text {hitung }} 2,665>\mathrm{t}_{\text {tabel }}$ 1,980 maka dapat disimpulkan bahwa terdapat pengaruh langsung rasa percaya diri terhadap penguasaan konsep matematika.

3) Pengujian Hipotesis ketiga

$\mathrm{H}_{0}$ : terdapat pengaruh langsung kecerdasan emosional terhadap rasa percaya diri

$\mathrm{H}_{1}$ : tidak terdapat pengaruh langsung kecerdasan emosional terhadap rasa percaya diri

Berdasarkan analisis jalur diketahui bahwa koefisien jalur variabel kecerdasan emosional terhadap rasa percaya diri $P_{21}=0,614$. Untuk $\alpha=0,05$ pada uji dua pihak diperoleh nilai $\mathrm{t}_{\text {tabel }}=1,980$, karena nilai $\mathrm{t}_{\text {hitung }} 6,644>\mathrm{t}_{\text {tabel }} 1,980$ maka dapat disimpulkan bahwa terdapat pengaruh langsung yang signifikan antara kecerdasan emosional terhadap rasa percaya diri.

3. Interpretasi Hasil Penelitian

Berdasarkan data penelitian tersebut, dideskripsikan sebagai berikut.

a. Pengaruh langsung kecerdasan emosional terhadap penguasaan konsep matematika Bahwa kecerdasan emosional yang diukur oleh penguasaan konsep matematika, menunjukan adanya kolerasi yang signifikan dan memiliki pengaruh langsung yang kuat terhadap penguasaan konsep matematika hal ini ditunjukkan oleh angka koefisien korelasi sebesar 0,563. Berdasarkan data hasil penelitian di atas dapat 
disimpulkan bahwa terdapat pengaruh langsung kecerdasan emosional terhadap penguasaan konsep matematika.

b. Pengaruh langsung rasa percaya diri terhadap penguasaan konsep matematika

Bahwa rasa percaya diri yang diukur oleh penguasaan konsep matematika, menunjukan adanya kolerasi yang signifikan dan memiliki pengaruh langsung yang kuat hal ini ditunjukkan oleh angka koefisien korelasi sebesar 0,541. Berdasar data hasil penelitian di atas dapat disimpulkan bahwa terdapat pengaruh langsung rasa percaya diri siswa terhadap penguasaan konsep matematika.

\section{c. Pengaruh langsung kecerdasan emosional terhadap rasa percaya diri}

Bahwa kecerdasan emosional yang diukur oleh rasa percaya diri, menunjukkan angka koefisien korelasi sebesar 0,614 sehingga dapat disimpulkan bahwa terdapat pengaruh langsung yang signifikan antara kecerdasan emosional terhadap rasa percaya diri.

Tabel 13. Rekapitulasi Koefisien Korelasi dan Koefisien Jalur

\begin{tabular}{clcc}
\hline No. & Hubungan Pengaruh Langsung & $\begin{array}{c}\text { Koefisien } \\
\text { Korelasi }\end{array}$ & $\begin{array}{c}\text { Koefisien } \\
\text { Jalur }\end{array}$ \\
\hline 1 & $\begin{array}{l}\text { Kecerdasan Emosional terhadap } \\
\text { Penguasaan Konsep }\end{array}$ & $r_{13}=0,563$ & $P_{31}=0,371$ \\
2 & $\begin{array}{l}\text { Rasa Percaya Diri terhadap } \\
\text { Penguasaan Konsep }\end{array}$ & $r_{23}=0,541$ & $P_{32}=0,314$ \\
3 & $\begin{array}{l}\text { Kecerdasan Emosional terhadap } \\
\text { Rasa Percaya Diri }\end{array}$ & $r_{12}=0,614$ & $P_{21}=0,614$ \\
\hline
\end{tabular}

\section{KESIMPULAN}

Berdasarkan hasil penelitian dan hasil pengujian hipotesis, menunjukkan bahwa:

1. Terdapat pengaruh langsung yang signifikan antara kecerdasan emosional terhadap penguasaan konsep matematika, yang dibuktikan dengan nilai $t_{\text {hitung }}(3,151)>t_{\text {tabel }}$ $(1,980)$, dan berdasarkan hasil analisis data tersebut dapat dideskripsikan bahwa variabel kecerdasan emosional memiliki pengaruh yang signifikan terhadap penguasaan konsep matematika.

2. Terdapat pengaruh langsung yang signifikan antara rasa percaya diri siswa terhadap penguasaan konsep matematika, yang dibuktikan dengan nilai $t_{\text {hitung }}(2,665)>\mathrm{t}_{\text {tabel }}$ $(1,980)$, dan berdasarkan hasil analisis data tersebut dapat dideskripsikan bahwa variabel rasa percaya diri memiliki pengaruh yang signifikan terhadap penguasaan konsep matematika. 
3. Terdapat pengaruh yang signifikan antara kecerdasan emosional terhadap rasa percaya diri, dan hal tersebut dibuktikan dengan nilai $\mathrm{t}_{\text {hitung }}(6,644)>\mathrm{t}_{\text {tabel }}(1,980)$, dan berdasarkan hasil analisis data tersebut dapat dideskripsikan bahwa variabel kecerdasan emosional berpengaruh terhadap kecerdasan emosional. Kecerdasan emosi yang merupakan kemampuan untuk mengenali diri sendiri, kemampuan untuk bergaul dan berinteraksi dengan orang lain, kemampuan untuk bersikap realistis, kemampuan untuk tetap tenang dan mampu bertahan dalam menghadapi konflik, serta kemampuan untuk mempertahankan sikap optimis dipandang dapat memberikan kontribusi terhadap rasa percaya diri siswa khususnya pada mata pelajaran matematika.

Proses belajar sewajarnya harus mendorong siswa untuk terlibat dalam proses mengubah kehidupannya kearah yang lebih baik serta dapat mengembangkan rasa percaya diri dan mengembangkan rasa ingin tahu dan juga meningkatkan pengetahuan maupun keterampilan. Terjadinya proses perubahan sikap dan tata laku seseorang atau kelompok orang dalam usaha mendewasakan manusia melalui upaya pengajaran, bimbingan dan pelatihan Dengan demikian tujuan pembelajaran diharapkan dapat berperan untuk meningkatkan kualitas siswa dalam proses pembelajaran.

\section{DAFTAR PUSTAKA}

Abdullah, S. I. (2014). Aplikasi Komputer Dalam Penyusunan Karya Ilmiah. Tangerang: Pustaka Mandiri.

Abdullah, S. I. (2015). Kompilasi Definisi dan Referensi Variabel Kependidikan. Jakarta: Lembaga Responsible Development International Indonesia (Lembaga RDII).

Emzir. (2014). Metodologi Penelitian Pendidikan Kuantitatif \& Kualitatif. Jakarta: Rajawali Pers.

Firmansyah, I. (2010). Pengaruh Tingkat Kecerdasan Emosional Terhadap Prestasi Belajar Siswa SMA Triguna Utama Ciputat. Jakarta: UIN Syarif Hidayatullah Jakarta.

Gusniwati, M. (2015). Pengaruh kecerdasan Emosional dan Minat Belajar Terhadap Penguasaan Konsep Matematika Siswa SMAN di Kecamatan Kebon Jeruk. Jurnal Formatif. Jurnal Ilmiah Pendidikan MIPA, Vol.5, No.1, 26-41.

Muhamad, N. (2016). Pengaruh Metode Discovery Learning untuk Meningkatkan Representasi Matematis dan Percaya Diri Siswa. Jurnal Pendidikan Universitas Garut, Vol.9, No.1, 9-22.

Nasution. (2005). Didakdik Asas-asas Mengajar. Jakarta: Rajawali Pers.

Pohan, A. (2005). Be Smart Leader. Jakarta: Pustaka Grahatama.

Rohayati, I. (2011). Program Bimbingan Teman Sebaya Untuk Meningkatkan Percaya Diri Siswa. Jurnal UPI Edisi Khusus, 1(1), 368-376.

Russeffendi, E. T. (2006). Pengantar Kepada Guru Mengembangkan Kompetensinya Dalam Pengajaran Matematika untuk Meningkatkan CBSA. Bandung: Tarsito.

Safaria, T \& Saputra, N. E. (2012). Manajemen Emosi. Jakarta: Bumi Aksara.

Sajiman, S. U. (2013). Hasil Belajar Matematika Siswa Ditinjau Dari Interaksi Tes Formatif Uraian Dan Kecerdasan Emosional. Jurnal Formatif, Vol.3, No. 2, 78-96. 
Shapiro, L. E. (2001). Mengajarkan Emotional Intelegence Pada Anak, Alih bahasa Alex Tri Kanatjono. Jakarta: PT. Gramedia Pustaka Utama.

Sudaryono. (2012). Pembelajaran Matematika di Sekolah Dasar. Bandung: Remaja Rosda Karya.

Sudjana, N. (2010). Penilaian Hasil Proses Belajar Mengajar. Bandung: PT Remaja Rosdakarya.

Sugiyono. (2011). Statistika Untuk Penelitian. Bandung: Alfabeta.

Sumardiono. (2006). Dasar-dasar Proses Belajar Mengajar. Bandung: Sinar Baru Algesindo.

Uno, H. B. (2010). Orientasi Baru dalam Psikologi Pembelajaran. Jakarta: Bumi Aksara. Yahya, M. (2009). Pengantar Pendidikan. Bandung: Prospect. 
62 Pengaruh Kecerdasan Emosional dan Rasa Percaya Diri Terhadap Penguasaan Konsep Matematika 